\title{
Nutrients Content and Uptake by Summer Cowpea [Vigna unguiculata L.] as Influenced by Different Nutrient Management Practices under South Gujarat Condition
}

\author{
Sejal Bhagariya ${ }^{1 *}$, K. A. Shah ${ }^{2}$ and K. M. Chaudhry ${ }^{1}$ \\ ${ }^{1}$ Department of Agronomy, Navsari, ${ }^{2}$ Krishi Vigyan Kendra, Agricultural University, Eru \\ Char Rasta, Navsari, Gujarat \\ *Corresponding author
}

\section{A B S T R A C T}

Keywords

Cowpea, FYM, Yield and Nutrients managements

Article Info

Accepted:

22 October 2020

Available Online:

10 November 2020
A field experiment was conducted during summer season of 2019 at the college farm, Navsari Agricultural University, Navsari to study the "Effect of different nutrient management practices on yield and nutrients content and uptake of summer cowpea [Vigna unguiculata L.] under south Gujarat condition". The soil of the experimental field was clayey in texture having medium to poor drainage, low in available nitrogen and organic carbon, medium in available phosphorus and high in available potassium. Total eight treatments viz., Control $\left(\mathrm{T}_{1}\right)$, FYM 5 t/ha $\left(\mathrm{T}_{2}\right)$, $100 \%$ RDF (20:40:00:20 NPKS kg/ha) $\left(\mathrm{T}_{3}\right), \mathrm{FYM} 5 \mathrm{t} / \mathrm{ha}+50 \% \mathrm{RDF}\left(\mathrm{T}_{4}\right), \mathrm{FYM} 5 \mathrm{t} / \mathrm{ha}+100 \% \mathrm{RDF}\left(\mathrm{T}_{5}\right), \mathrm{FYM} 5 \mathrm{t} / \mathrm{ha}+50 \%$ $\mathrm{RDF}+1 \%$ spray of EBPS at 30 DAS and 60 DAS $\left(\mathrm{T}_{6}\right), \mathrm{FYM} 5 \mathrm{t} / \mathrm{ha}+100 \% \mathrm{RDF}+1 \%$ spray of EBPS at 30 DAS and 60 DAS $\left(\mathrm{T}_{7}\right)$ and FYM 5 t/ha $+100 \%$ RDF $+1 \%$ spray of urea at 60 DAS $\left(\mathrm{T}_{8}\right)$ were tested in randomized block design with three replications. An application of FYM 5 t/ha $+100 \%$ RDF $+1 \%$ spray of EBPS at 30 DAS and 60 DAS recorded significantly higher seed yield, haulm yield, N, P and K content and uptake in seed and haulm of cowpea over control. Maximum gross return of 99932 Rs/ha, net return of 58957 Rs/ha with BCR 2.44 were also incurred under same treatment.

\section{Introduction}

In India, frequency of pulses consumption is much higher than any other source of protein, which indicates the importance of pulses in their daily food habits. The domestic production of pulses was around 25.3 million tonnes with the productivity of $841 \mathrm{~kg} / \mathrm{ha}$ (Anonymous, 2018). Pulses production in India has not kept up with growth in demand calling for import to the tune of 2.0 to 4.0 million tonnes (Raj et al., 2013). As per recommendation of WHO minimum requirement of pulses is $80 \mathrm{~g} /$ capita/day, but it is available less than $50 \mathrm{~g} /$ capita/day. Therefore, the production and productivity needs to improve to satisfied the demand of ever increasing population.

Cowpea (Vigna unguiculata L. Walp) is one of the most important pulse crops native of Central Africa and belong to family 
Leguminoceae. Cowpea is called as vegetable meat due to high content of protein in grain (23.4\%), with better biological value on dry weight basis. It also contents highly nutritious constitution of fat $(1.8 \%)$ and carbohydrates $(60.3 \%)$ as well as rich source of $\mathrm{Ca}$ and $\mathrm{Fe}$. Apart from this, cowpea forms excellent forage, fodder as hay, green fodder and concentrates and it produces a heavy vegetative growth and covers the ground thereby, it checks the soil erosion. Cowpea known to improve soil fertility as they fix atmospheric nitrogen in soil at the rate of 80$85 \mathrm{~kg} / \mathrm{ha}$ through symbiotic nitrogen fixation with the help of bacterium called Rhizobia. Thus cowpea plant is a mini-fertilizer factory itself.

Cowpea is a warm-season crop well adapted to many areas of the humid tropics and temperate zones. In India, it is cultivated in 654 lakh ha with an annual production of 599 lakh tonnes leading to average productivity of $916 \mathrm{~kg} / \mathrm{ha}$ (Anonymous, 2015). The area under cowpea cultivation in Gujarat is about 0.27 lakh hectares with an annual production of 2.89 lakh tonnes and the productivity of $1049 \mathrm{~kg} / \mathrm{ha}$ (Anonymous, 2012).

The combined use of organic and inorganic sources of plant nutrient not only improved the production and profitability of field crops, rather it helps in maintaining the permanent fertility status of soil (Kumar and Singh, 2010). Incorporation of FYM or organic manure alone or integration with chemical fertilizers improves not only the nutrient use efficiency, but also increases available nutrient status of soil with enhanced soil biological activity which in turn provides a congenial physical condition and improved availability of nutrient in the rhizosphere (Kanwar et al., 2017). Further, it helps in mineralization of nutrients in the rhizosphere improves crop growth and provides a better source-sink relationship by enhancing synthesis and allocation of metabolites to reproductive organs.

Foliar spray technique helps the nutrients to reach the site of food synthesis directly, leading to no wastage and quick supply of food and thereby reduce the requirement of fertilizers. Moreover, foliage feeding practices would be more useful in early maturing crop, which could be combined with regular plant protection programmes. If foliar nutrition is applied, it reduces the cost of cultivation which in turn reduces the amount of fertilizers thereby reduce the loss and also economizing crop production. Foliar application of urea at 50\% flowering increased the yield and seed protein. In legumes, leaf senescence starts earlier before completion of maturity which break the source to sink relation, thereby reduce the yield. Nitrogen spray has been found to delay leaf senescence and improve yield (Palta et al., 2005).

Recently, integrated nutrient management has emerged as a sustainable practice which is able to boost up production, productivity and quality of the product, without causing any negative hazardous effect on crop and environment. Cultivation of cowpea in summer season is increasing in Gujarat, especially in south Gujarat. Therefore this experiment has been planned to study the Effect of different nutrient management practices on yield and nutrients content and uptake of summer cowpea [Vigna unguiculata L.] under south Gujarat condition" during summer season of 2019.

\section{Materials and Methods}

A field experiment was conducted in summer season of 2019 at the college farm, Navsari Agricultural University, Navsari, Gujarat. The soil of the experimental field was clayey in texture having medium to poor drainage, soil 
$\mathrm{pH} 8.08$, EC $0.50 \mathrm{ds} / \mathrm{m}$ and organic carbon content $0.40 \%$. The soil is low in available nitrogen $(213.87 \mathrm{~kg} / \mathrm{ha})$, medium in available phosphorus $(34.27 \mathrm{~kg} / \mathrm{ha})$ and high in available potassium (312.10 $\mathrm{kg} / \mathrm{ha})$ were determined by Kjeldahl's method, Olsen's method and Flame photometric method, respectively. Total eight treatments viz., Control $\left(\mathrm{T}_{1}\right)$, FYM 5 t/ha $\left(\mathrm{T}_{2}\right), 100 \% \mathrm{RDF}$ (20:40:00:20 NPKS kg/ha) $\left(\mathrm{T}_{3}\right)$, FYM 5 t/ha $+50 \% \mathrm{RDF}\left(\mathrm{T}_{4}\right), \mathrm{FYM} 5 \mathrm{t} / \mathrm{ha}+100 \% \mathrm{RDF}$ $\left(\mathrm{T}_{5}\right)$, FYM 5 t/ha $+50 \%$ RDF $+1 \%$ spray of EBPS at 30 DAS and 60 DAS $\left(\mathrm{T}_{6}\right)$, FYM 5 $\mathrm{t} / \mathrm{ha}+100 \% \mathrm{RDF}+1 \%$ spray of EBPS at 30 DAS and 60 DAS $\left(\mathrm{T}_{7}\right)$ and FYM 5 t/ha +100 $\%$ RDF $+1 \%$ spray of urea at 60 DAS $\left(\mathrm{T}_{8}\right)$ were tested in randomized block design with three replications. Cowpea variety "GC-4" seeds were sown at $45 \times 15 \mathrm{~cm}$ spacing. Farm yard manure was incorporated about 15 days before sowing in soil as per treatments. The entire dose of fertilizer was applied as per the treatments at basal application just before sowing and spraying of enriched banana pseudostem sap and urea were applied as per the treatments. Enriched banana pseudostem sap is first time prepared and patented by Navsari Agricultural University, Navsari which was developed by team of National Innovative Project on "A Value Chain on Utilization of Banana Pseudostem for Fiber and Other Value Added products." This enriched sap is a very good source of essential plant nutrients namely $\mathrm{N}(70.0 \mathrm{mg} / \mathrm{l}), \mathrm{P}(26.1$ $\mathrm{mg} / \mathrm{l}), \mathrm{K}(170 \mathrm{mg} / \mathrm{l}), \mathrm{Fe}$ (7.44 mg/l), Mn (2.66 $\mathrm{mg} / \mathrm{l}), \mathrm{Zn}(0.40 \mathrm{mg} / \mathrm{l}), \mathrm{Cu}(0.26 \mathrm{mg} / \mathrm{l})$ etc. as well as hormones $\mathrm{GA}_{3}$ and cytokinin. Urea, DAP and gypsum were taken as fertilizer sources for $\mathrm{N}, \mathrm{P}$ and $\mathrm{S}$, respectively. All other operation was performed as per recommendations of the crops. The observation on $\mathrm{N}, \mathrm{P}$ and $\mathrm{K}$ content (\%) and uptake $(\mathrm{kg} / \mathrm{ha})$ by seed and haulm were analyzed and recorded from random samples of plants and seed collected from each net plot area. The samples were oven dried at $60^{\circ} \mathrm{C}$ for 24 hours, powdered by mechanical grinder and analyzed for respective nutrient content using following procedure. The results were analysis statistically to draw suitable interference as per the standard ANOVA techniques suggested by Gomez and Gomez (1984).

\begin{tabular}{|c|c|c|c|}
\hline $\begin{array}{c}\text { Sr. } \\
\text { No. }\end{array}$ & $\begin{array}{c}\text { Nutrients } \\
(\mathbf{\%})\end{array}$ & Method & Reference \\
\hline 1. & Nitrogen & $\begin{array}{c}\text { Modified Kjeldahl's } \\
\text { method }\end{array}$ & $\begin{array}{c}\text { Jackson } \\
(1973)\end{array}$ \\
\hline 2. & Phosphorus & $\begin{array}{c}\text { Vanadomolybdo } \\
\text { phosphoric acid } \\
\text { Yellow colour } \\
\text { method }\end{array}$ & $\begin{array}{c}\text { Jackson } \\
(1973)\end{array}$ \\
\hline 3. & Potassium & $\begin{array}{c}\text { Flame photometric } \\
\text { method }\end{array}$ & $\begin{array}{c}\text { Jackson } \\
(1973)\end{array}$ \\
\hline
\end{tabular}

\section{Results and Discussion}

\section{Seed and haulm yield}

The seed and haulm yields of cowpea (Table1) significantly influenced by different nutrient management treatments. An application of FYM 5 t/ha $+100 \%$ RDF +1 $\%$ spray of EBPS at 30 and 60 DAS $\left(\mathrm{T}_{7}\right)$ produced significantly higher seed yield (1744 kg/ha) of cowpea over control, but it was statistically at par with application of FYM 5 t/ha $+100 \%$ RDF $+1 \%$ spray of urea at 60 DAS (1657 kg/ha) and FYM 5 t/ha $+50 \% \mathrm{RDF}+1 \%$ spray of EBPS at 30 and 60 DAS (1619 kg/ha).

The haulm yield (4238 kg/ha) was observed significantly higher with application of FYM $5 \mathrm{t} / \mathrm{ha}+100 \% \mathrm{RDF}+1 \%$ spray of EBPS at 30 and 60 DAS $\left(T_{7}\right)$ over rest of the treatments except, the application of FYM 5 t/ha $+100 \% \mathrm{RDF}+1 \%$ spray of urea at 60 DAS (4124 kg/ha), FYM 5 t/ha + $50 \%$ RDF $+1 \%$ spray of EBPS at 30 and 60 DAS (4103 $\mathrm{kg} / \mathrm{ha})$ and FYM 5 t/ha $+100 \%$ RDF (3883 $\mathrm{kg} / \mathrm{ha}$ ). The remarkable lowest seed yield (924 $\mathrm{kg} / \mathrm{ha})$ and haulm yield (2970 kg/ha) of cowpea were obtained under control. There 
were $88.74,79.33$ and 75.22 per cent seed yield and 42.69, 38.86 and 38.17 per cent haulm yield increased under the treatment $\mathrm{T}_{7}$, $\mathrm{T}_{8}$ and $\mathrm{T}_{6}$ over the control, respectively.

Table.1 Effect of different nutrient management practices on yield and economics of cowpea

\begin{tabular}{|c|c|c|c|c|c|c|}
\hline \multirow[t]{2}{*}{ Treatments } & \multicolumn{2}{|c|}{ Yield (kg/ha) } & \multirow{2}{*}{$\begin{array}{c}\text { Cost of } \\
\text { cultivation } \\
\text { (Rs/ha) }\end{array}$} & \multirow{2}{*}{$\begin{array}{l}\text { Gross } \\
\text { income } \\
\text { (Rs/ha) }\end{array}$} & \multirow{2}{*}{$\begin{array}{c}\text { Net } \\
\text { profit } \\
\text { (Rs/ha) }\end{array}$} & \multirow[t]{2}{*}{ BCR } \\
\hline & Seed & Haulm & & & & \\
\hline $\mathbf{T}_{1:}$ Control & 924 & 2970 & 23295 & 55128 & 31833 & 2.37 \\
\hline$T_{2}:$ FYM 5 t/ha & 1106 & 3363 & 35181 & 65405 & 30224 & 1.86 \\
\hline $\begin{array}{l}T_{3}: 100 \% \text { RDF (20:40: 00:20 } \\
\text { NPKS kg/ha) }\end{array}$ & 1266 & 3619 & 27521 & 74141 & 46620 & 2.69 \\
\hline $\mathrm{T}_{4}: \mathrm{FYM} 5 \mathrm{t} / \mathrm{ha}+50 \% \mathrm{RDF}$ & 1318 & 3653 & 37294 & 76858 & 39564 & 2.06 \\
\hline $\mathrm{T}_{5}:$ FYM $5 \mathrm{t} / \mathrm{ha}+100 \% \mathrm{RDF}$ & 1527 & 3883 & 39023 & 87981 & 48958 & 2.25 \\
\hline $\begin{array}{l}T_{6}: \text { FYM } 5 t / h a+50 \% \text { RDF + } \\
1 \% \text { spray of EBPS at } 30 \\
\text { and } 60 \text { DAS }\end{array}$ & 1619 & 4103 & 39245 & 93276 & 54030 & 2.38 \\
\hline $\begin{array}{l}\text { T}_{7}: \text { FYM 5t/ha }+100 \% \text { RDF }+ \\
1 \% \text { spray of EBPS at } 30 \\
\text { and } 60 \text { DAS }\end{array}$ & 1744 & 4238 & 40975 & 99932 & 58957 & 2.44 \\
\hline $\begin{array}{l}\text { T }_{8}: \text { FYM } 5 t / \text { ha }+100 \% \text { RDF }+ \\
1 \% \text { spray of urea at } 60 \text { DAS }\end{array}$ & 1657 & 4124 & 39387 & 95239 & 55852 & 2.42 \\
\hline SEm \pm & 52.24 & 136.25 & - & - & - & - \\
\hline $\mathrm{CD}(\mathrm{P}=0.05)$ & 159.99 & 417.27 & - & - & - & - \\
\hline CV \% & 6.49 & 6.30 & - & - & - & - \\
\hline
\end{tabular}

Table.2 Effect of different nutrient management practices on major nutrients content in seed and haulm of cowpea

\begin{tabular}{|c|c|c|c|c|c|c|}
\hline \multirow[t]{2}{*}{ Treatment } & \multicolumn{3}{|c|}{ Nutrient content $(\%)$ in seed } & \multicolumn{3}{|c|}{ Nutrient content $(\%)$ in haulm } \\
\hline & $\mathrm{N}$ & $\mathrm{P}$ & $\mathrm{K}$ & $\mathrm{N}$ & $\mathrm{P}$ & K \\
\hline $\mathbf{T}_{1:}$ Control & 2.81 & 0.27 & 0.56 & 0.50 & 0.14 & 1.09 \\
\hline $\mathrm{T}_{2}:$ FYM $5 \mathrm{t} / \mathrm{ha}$ & 2.85 & 0.30 & 0.70 & 0.57 & 0.16 & 1.20 \\
\hline $\begin{array}{l}T_{3}: 100 \% \text { RDF (20:40: } \\
00: 20 \text { NPKS kg/ha) }\end{array}$ & 3.14 & 0.33 & 0.84 & 0.65 & 0.20 & 1.28 \\
\hline $\mathrm{T}_{4}:$ FYM $5 \mathrm{t} / \mathrm{ha}+50 \% \mathrm{RDF}$ & 2.92 & 0.31 & 0.71 & 0.61 & 0.19 & 1.25 \\
\hline $\mathrm{T}_{5}:$ FYM $5 \mathrm{t} / \mathrm{ha}+100 \% \mathrm{RDF}$ & 3.09 & 0.35 & 0.74 & 0.63 & 0.21 & 1.38 \\
\hline $\begin{array}{l}\mathrm{T}_{6}: \text { FYM } 5 \mathrm{t} / \mathrm{ha}+50 \% \mathrm{RDF}+ \\
1 \% \text { spray of EBPS at } 30 \text { and } 60 \text { DAS }\end{array}$ & 3.24 & 0.34 & 0.80 & 0.64 & 0.20 & 1.39 \\
\hline $\begin{array}{l}\mathrm{T}_{7}: \mathrm{FYM} 5 \mathrm{t} / \mathrm{ha}+100 \% \mathrm{RDF}+ \\
1 \% \text { spray of EBPS at } 30 \\
\text { and } 60 \text { DAS }\end{array}$ & 3.36 & 0.37 & 0.89 & 0.70 & 0.22 & 1.45 \\
\hline $\begin{array}{l}\mathrm{T}_{8:} \text { FYM } 5 \mathrm{t} / \mathrm{ha}+100 \% \mathrm{RDF}+ \\
1 \% \text { spray of urea at } 60 \mathrm{DAS}\end{array}$ & 3.33 & 0.36 & 0.87 & 0.65 & 0.21 & 1.41 \\
\hline SEm \pm & 0.12 & 0.02 & 0.06 & 0.03 & 0.02 & 0.07 \\
\hline $\mathrm{CD}(\mathrm{P}=0.05)$ & 0.37 & 0.06 & 0.18 & 0.10 & 0.05 & 0.22 \\
\hline CV \% & 6.81 & 9.99 & 13.60 & 9.55 & 13.67 & 9.33 \\
\hline
\end{tabular}


Table.3 Effect of different nutrient management practices on nutrients uptake of cowpea seed and haulm

\begin{tabular}{|c|c|c|c|c|c|c|c|c|c|}
\hline \multirow[t]{2}{*}{ Treatments } & \multicolumn{3}{|c|}{$\begin{array}{l}\text { Nutrient uptake }(\mathrm{kg} / \mathrm{ha}) \\
\text { by seed }\end{array}$} & \multicolumn{3}{|c|}{$\begin{array}{l}\text { Nutrient uptake (kg/ha) } \\
\text { in haulm }\end{array}$} & \multicolumn{3}{|c|}{$\begin{array}{l}\text { Total nutrient uptake } \\
\text { (kg/ha) }\end{array}$} \\
\hline & $\mathrm{N}$ & $\mathrm{P}$ & $\mathrm{K}$ & $\mathrm{N}$ & $\mathrm{P}$ & K & $\mathrm{N}$ & $\mathrm{P}$ & K \\
\hline$T_{1:}$ Control & 26.01 & 2.51 & 5.18 & 14.90 & 4.04 & 32.32 & 40.92 & 6.55 & 37.50 \\
\hline$T_{2:}$ FYM 5 t/ha & 31.52 & 3.30 & 7.76 & 19.10 & 5.22 & 40.36 & 50.62 & 8.51 & 48.13 \\
\hline $\begin{array}{l}T_{3}: 100 \% \text { RDF (20: } \\
\text { 40:00:20 NPKS kg/ha) }\end{array}$ & 39.65 & 4.20 & 10.67 & 23.59 & 7.40 & 46.09 & 63.23 & 11.60 & 56.76 \\
\hline T $_{4}:$ FYM 5 t/ha + 50\% RDF & 38.46 & 4.12 & 9.44 & 22.21 & 6.97 & 45.77 & 60.67 & 11.09 & 55.21 \\
\hline T $_{5:}$ FYM 5 t/ha + 100\% RDF & 47.01 & 5.42 & 11.32 & 24.42 & 8.11 & 53.70 & 71.43 & 13.53 & 65.01 \\
\hline $\begin{array}{l}\text { T }_{6}: \text { FYM } 5 \text { t/ha }+50 \% \\
\text { RDF }+1 \% \text { spray of } \\
\text { EBPS at } 30 \text { and } 60 \text { DAS }\end{array}$ & 52.38 & 5.44 & 12.96 & 26.02 & 8.33 & 57.20 & 78.40 & 13.77 & 70.16 \\
\hline $\begin{array}{l}\text { T }_{7}: \text { FYM } 5 \mathrm{t} / \mathrm{ha}+ \\
100 \% \mathrm{RDF}+1 \% \\
\text { spray of EBPS at } 30 \text { and } 60 \text { DAS }\end{array}$ & 58.59 & 6.46 & 15.51 & 29.48 & 9.17 & 61.46 & 88.07 & 15.63 & 76.97 \\
\hline $\begin{array}{l}\text { T}_{8}: \text { FYM 5t/ha }+100 \% \\
\text { RDF }+1 \% \text { spray of urea at } 60 \text { DAS }\end{array}$ & 55.22 & 5.97 & 14.36 & 26.88 & 8.63 & 58.46 & 82.10 & 14.60 & 72.82 \\
\hline SEm \pm & 2.01 & 0.32 & 1.14 & 1.59 & 0.59 & 3.71 & 2.64 & 0.66 & 4.24 \\
\hline $\mathrm{CD}(\mathrm{P}=0.05)$ & 6.17 & 0.99 & 3.49 & 4.86 & 1.82 & 11.35 & 8.09 & 2.01 & 12.99 \\
\hline $\mathrm{CV} \%$ & 8.00 & 12.01 & 18.16 & 11.78 & 14.21 & 12.99 & 6.84 & 9.55 & 12.18 \\
\hline
\end{tabular}

The increase in seed yield with application of different nutrient management treatments was mainly due to cumulative effect of significant increased in the growth and yield attributing character viz., number of branches, number of pods per plant, pod length and number of seeds per pod. Similarly, the haulm yield was remarkably increased due to the significant improvement in the growth attributing characters viz., plant height and number of branches per plant.

The overall improvement in all the growth and yield attributing components may be due to synergistic effect of combined use of organic and inorganic manures as well as foliar spray at critical crop growth stage. These results are in line with those published by Chaudhry and Yadav (2011), Devi et al., (2013), Meena et al., (2014), Patel et al., (2015), Dhakal et al., (2016), Joshi et al., (2018) and Shroti et al., (2018).

\section{Nutrient content and uptake}

The concentration of $\mathrm{N}, \mathrm{P}$ and $\mathrm{K}$ content in seed and haulm were significantly affected by application of different nutrient management treatments (Table 2). An application of FYM $5 \mathrm{t} / \mathrm{ha}+100 \%$ RDF $+1 \%$ spray of EBPS at 30 and 60 DAS $\left(\mathrm{T}_{7}\right)$ was recorded significantly higher nitrogen, phosphorus and potassium content in seed $(3.36 \%, 0.37 \%$ and $0.89 \%)$ and haulm $(0.70 \%, 0.22 \%$ and $1.45 \%$ ) over control, respectively, but it was at par with rest of treatments, except under the FYM 5 t/ha in case of all major nutrients contents in seed and haulm and FYM 5 t/ha + $50 \%$ RDF in case of the nitrogen contents in seed. This might be due to the fact that plant absorbed proportionately high amount of $\mathrm{N}, \mathrm{P}$ and $\mathrm{K}$ as the pool of available nutrients increased in the soil by adding combination of organic and inorganic fertilizers. The increased availability of these nutrients in the root zone coupled with increased metabolic 
activity at cellular levels might have increased nutrient uptake and their accumulation in the vegetative part of plants. An improved metabolism further helps in greater translocation of these nutrients to reproductive organs of the crop and ultimately increased the nutrients content in seed and straw. Moreover, along with this foliar spray of readily available form of nutrients to plant at critical growth stages further helps in increase the concentration of nutrients in plant. These findings are substantiated with those reported by Kumawat et al., (2009), Patil et al., (2010), Chaudhary et al., (2013) and Dhakal et al., (2016).

However, the variation in uptake of all the major nutrients by seeds and haulm was remarkably differed with different nutrient management treatments (Table 3). Among the different nutrient management practices, treatments FYM 5 t/ha $+100 \% \mathrm{RDF}+1 \%$ spray of EBPS at 30 and 60 DAS $\left(T_{7}\right)$ recorded significantly superior uptake of $\mathrm{N}, \mathrm{P}$ and $\mathrm{K}$ by seed over rest of the treatments, except under the treatment $\mathrm{T}_{8}$ in case of $\mathrm{N}, \mathrm{P}$ and $\mathrm{K}$ uptake by seed and $\mathrm{T}_{6}$ in case of $\mathrm{K}$ uptake by seed. However, significantly the lowest uptake of $\mathrm{N}, \mathrm{P}$ and $\mathrm{K}$ by cowpea seed were registered $26.01,2.51$ and $5.18 \mathrm{~kg} / \mathrm{ha}$ under the control, respectively. The uptake of $\mathrm{N}$ (29.48 kg/ha), P (9.17 kg/ha) and K (61.46 $\mathrm{kg} / \mathrm{ha}$ ) by haulm of cowpea were recorded significantly higher with the application of FYM 5 t/ha $+100 \%$ RDF $+1 \%$ spray of EBPS at 30 and 60 DAS $\left(\mathrm{T}_{7}\right)$ over control, but it was remain at par with the treatment FYM 5 $\mathrm{t} / \mathrm{ha}+100 \% \mathrm{RDF}+1 \%$ spray of urea at 60 DAS and FYM 5 t/ha $+50 \%$ RDF $+1 \%$ spray of EBPS at 30 and 60 DAS in case of all the major nutrients uptake by haulm and FYM 5 t/ha $+100 \%$ RDF in case of only phosphorus and potassium uptake by haulm. However, significantly the lowest uptake of $\mathrm{N}, \mathrm{P}$ and $\mathrm{K}$ by haulm were registered 14.90 , 4.04 and $32.32 \mathrm{~kg} / \mathrm{ha}$ under the control, respectively. The higher uptake of all these nutrients by seed and haulm might be due to increase in concentration of these nutrients coupled with increasing the yield of seed and haulm under the same treatment. Similar trend was also observed in case of total uptake of nitrogen, phosphorus and potassium by crop. An application of FYM 5 t/ha $+100 \%$ RDF + $1 \%$ spray of EBPS at 30 and $60 \mathrm{DAS}\left(\mathrm{T}_{7}\right)$ recorded significantly higher total uptake of $\mathrm{N}$ (88.07 kg/ha), P (15.63 kg/ha) and K (76.97 $\mathrm{kg} / \mathrm{ha}$ ) over control, which were remain at par with the treatment of FYM 5 t/ha $+100 \%$ $\mathrm{RDF}+1 \%$ spray of urea at 60 DAS in case of total uptake of all major nutrients, FYM 5 t/ha $+50 \% \mathrm{RDF}+1 \%$ spray of EBPS at 30 and 60 DAS in case of total $\mathrm{P}$ uptake and total $\mathrm{K}$ uptake and FYM 5 t/ha $+100 \% \mathrm{RDF}$ in case of total $\mathrm{K}$ uptake. These results are in accordance with Kumawat et al., (2009), Patil et al., (2010), Kuttimani and Velayutham (2011), Chaudhary et al., (2013), and Tyagi et al., (2014) with respect to $\mathrm{N}, \mathrm{P}$ and $\mathrm{K}$ uptake and total nutrients uptake.

\section{Economics}

The data presented in Table 1 revealed that an application of FYM 5 t/ha $+100 \%$ RDF +1 $\%$ spray of EBPS at 30 and 60 DAS incurred maximum gross realization (99932 ₹ /ha) and net realization (58957 ₹ /ha) with BCR (2.44), which was closely followed by the treatment FYM 5 t/ha $+100 \%$ RDF $+1 \%$ spray of urea at 60 DAS record gross realization of 95239 ₹/ha, net realization 55852 ₹/ha and $\mathrm{B}$ : $\mathrm{C}$ ratio of 2.42. Whereas, the highest $\mathrm{B}: \mathrm{C}$ ratio of 2.69 was recorded with the $100 \%$ RDF (20:40:00:20 kg NPKS/ha). The higher gross and net returns found under the combination of inorganic and organic fertilizers with the foliar spray of nutrients might be due to higher seed yield obtained as compared to cost involved under this treatment. The lowest gross realization of ₹ 55128/ha was obtained under the control 
treatment, where as lowest net realization of ₹ 30224/ha and BCR of 1.86 was obtained under the treatment FYM 5 t/ha. It might be due to lower yield under control and high cost of FYM. The increases in the net return with the integration of $5 \mathrm{t} \mathrm{FYM/ha} \mathrm{with} 100 \%$ RDF along with foliar spay of $1 \%$ EBPS at 30 and 60 DAS over control, FYM 5 t/ha and $100 \%$ RDF were 46.0, 48.73 and 20.93 per cent, respectively. Similar views in direction of present finding were also expressed by Kuttimani and Velayutham (2011), Devi et al., (2013) and Verma et al., (2018).

In conclusion from the one year experimental results, it can be proved that an application of FYM 5 t/ha + 50\% RDF (10:20:00:10 kg NPKS/ha) + $1 \%$ spray of EBSP at 30 and 60 DAS not only increases the seed and haulm yield, but also improved the nutrients content and uptake by seed and haulm of cowpea. Integrated use of organic, inorganic and foliar spray of enrich banana pseudostem sap may be suggested for the higher yield and economic return and it will be useful to enhance the productivity of summer cowpea.

\section{References}

Anonymous (2012). Ministry of Agriculture and Farmers Welfare, Government of India.

Anonymous (2015). Ministry of Agriculture and Farmers Welfare, Government of India.

Anonymous (2018). Ministry of Agriculture and Farmers Welfare, Government of India.

Chaudhary, G.L. and Yadav, L.R. (2011). Effect of fertility levels and foliar nutrition on cowpea productivity. Journal of Food Legumes, 24(1): 67-68.

Chaudhary, H.R., Sharma, O.P., Singh, R.K., Singh, K., Kumar, R. and Yadav, L. (2013). Influence of organic manures and chemical fertilizer on nutrient uptake, yield and profitability of mungbean [Vigna radiata (L.) Wilczek]. Madras Agricultural Journal, 100(1-3): 747-750.

Devi, K.N., Singh, T.B., Athokpam, H.S. and Brajendra, N. (2013). Infiluence of inorganic, biological and organic manures on nodulation and yield of soybean (Glycine max Merril L.) and soil properties. Australian Journal of Crop Science, 7(9): 1407-1415.

Dhakal, Y., Meena, R.S. and Kumar, S. (2016). Effect of INM on nodulation, yield, and quality and available nutrient status in soil after harvest of green gram. Legume Research, 39(4): 590594.

Gomez, K.A. and Gomez, A.A. 1984. Statistical Methods for Agricultural Research. John Wiley and Sons, New York, pp. 139-264.

Jackson, M.L. (1973). Soil Chemical Analysis. Prentice Hall of India Pvt. Ltd., New Delhi. pp: 205.

Joshi, J.R., Patel, V.M., Basrad, H.L., Macwan, S.M. and Ehsas, J. (2018). Effect of land configuration and fertilizer management practices on growth, yield and yield attributes and economics of summer cowpea (Vigna unguiculata L.) under south Gujarat condition. International Journal of Current Microbiology and Applied Sciences, 7(1): 1148-1155.

Kanwar, A, Sharma, S.R., Yadav, K.R and Yadav, G.L. (2017). Effect of organic and inorganic nutrition on fertility status of soil and yield of vegetable cowpea. Chemical Science Review and Letters, 6 (23), 1510-1514.

Kumar, V. and Singh, S.Y. (2010). Integrated nutrient management an ideal approach for enhancing agricultural production and productivity. Indian Journal of Fertilizers, 1(6): 41-53.

Kumawat, N., Kumar, R. and Sharma, O.P. 
(2009). Nutrient uptake and yield of mungbean Vigna radiata (L.) Wilczek as influenced by organic manures, PSB and phosphorus fertilization. Environment and Ecology, 27(4B): 2002-2005.

Kuttimani, R. and Velayutham, A. (2011). Foliar application of nutrients enhances the yield attributes and nutrient uptake of greengram. Agricultural Science Digest, 31 (3): 202-205.

Meena, J.S., Verma, H.P. and Pincholi, P. (2014). Effect of fertility levels and biofertilizers on yield, quality and economic of cowpea. Agriculture for Sustainable Development, 2(2): 162164.

Palta, J.A., Nandwal, A.S., Kumari, S. and Turner, N.C. (2005). Foliar nitrogen application increase the seed yield and protein content in chickpea (Cicer arietinum L.) subject to terminal drought. Australian Journal of Agricultural Research, 56: 105-112.

Patel, A.D., Patel, D.D., Patel, T.U. and Prajapati, D.R. (2015). Effect of integrated nutrient management on growth parameters, yield attributes and yield of summer greengram (Vigna radiata L.) under south Gujarat condition. AGRES-An international eJourna, 4(1), 72-78.
Patil, D.S., Khistaria, M.K. and Padmani, D.R. (2010). Effect of nutrient management and biofertilizer on quality, NPK content and uptake of blackgram in medium black soil. International Journal of Agricultural Sciences, 6(1), 167-168.

Raj, A.D., Yadav, V. and Rathod, J.H. (2013). Impact of front line demonstration (FLD) on the yield of pulses. International Journal of Scientific and Research Publication, 3(9): 2250-3153.

Shroti, S.K., Pathak, A., Tiwari, A., Gupta, A. and Chauhan, S.K. (2018). Morphological, physiological and yield analysis of black gram under different levels of FYM, PSB and phosphorus. International Journal of chemical Studies, 6(3): 403-411.

Tyagi, P.K., Upadhyay, A.K. and Raikwar, R. S. (2014). Integrated approach in nutrient management of summer green gram. The Bioscan, 9(4): 1529-1533.

Verma, H., Parihar, M. S., Nawange, D. D. and Sahu, M. K. 2018. Effect of integrated nutrient management on growth and yield of cowpea (Vigna unguiculata L. Walp). International Journal of Agriculture Sciences, 10(18): 7186-7188.

\section{How to cite this article:}

Sejal Bhagariya, K. A. Shah and Chaudhry, K. M. 2020. Nutrients Content and Uptake by Summer Cowpea [Vigna unguiculata L.] as Influenced by Different Nutrient Management Practices under South Gujarat Condition. Int.J.Curr.Microbiol.App.Sci. 9(11): 3357-3364. doi: https://doi.org/10.20546/ijcmas.2020.911.401 